\title{
Collective Action and Marketing of Underutilized Plant Species: The Case of Minor Millets in Kolli Hills, Tamil Nadu, India
}

Guillaume P. Gruère, International Food Policy Research Institute, Latha Nagarajan, International Food Policy Research Institute, and E.D.I. Oliver King, M.S. Swaminathan Research Foundation

\author{
Research Workshop on Collective Action and Market Access for Smallholders \\ October 2-5, 2006 - Cali, Colombia
}

The CGIAR Systemwide Program on Collective Action and Property Rights (CAPRi) is an initiative of the 15 centers that belong to the Consultative Group on International Agricultural Research. The initiative promotes comparative research on the role played by property rights and collective action institutions in shaping the efficiency, sustainability, and equity of natural resource systems. CAPRi's Secretariat is hosted by the International Food Policy Research Institute's (IFPRI) Environment and Production Technology Division (www.ifpri.org).

CAPRi Working Papers contain preliminary material and research results and are circulated prior to a full peer review in order to stimulate discussion and critical comment. It is expected that most Working Papers will eventually be published in some other form, and that their content may also be revised. http://dx.doi.org/10.2499/CAPRiWP69.

Copyright $\odot$ August 2007. International Food Policy Research Institute. All rights reserved. Sections of this material may be reproduced for personal and not-for-profit use without the express written permission of but with acknowledgment to IFPRI. To reproduce the material contained herein for profit or commercial use requires express written permission. To obtain permission to reprint, contact the IFPRI Communications Division at ifpri-copyright@cgiar.org.

CGIAR Systemwide Program on Collective Action and Property Rights (CAPRi) c/O INTERNATIONAL FOOD POLICY RESEARCH INSTITUTE 


\section{ACKNOWLEDGEMENTS}

The authors would like to thank the M.S Swaminathan Research Foundation, Chennai for their research collaboration and the staff working at the field stations of Namakkal and Kolli hills for their support in conducting the field visits. Further we would like to acknowledge the farm level participants and members of the enterprise and self-help groups in Kolli hills for patiently answering all our questions. 


\begin{abstract}
Minor millets are examples of underutilized plant species, being locally important but rarely traded internationally with an unexploited economic potential. In the Kolli hills of Tamil $\mathrm{Nadu}$, India, a genetically diverse pool of minor millet varieties are grown by the tribal farming communities to meet their subsistence food needs. Most of these minor crops were not traded outside the farming community. Despite a consumption preference among the farming communities for minor millets, in the recent past the acreage under minor millet crops have declined considerably due to the availability of substitute cash crops. As a response, the M.S. Swaminathan Research Foundation (MSSRF) based in Chennai has led targeted conservation cum commercialization intervention programs over the last 7-9 years in the Kolli Hills. In this paper we provide a first evaluation of the success of marketing development for minor millets in the Kolli Hills with a specific focus on collective action and group initiatives undertaken by the women and men self-help groups organized by the concerned non-governmental organization. We analyze the key collective actions that are taking place in the minor millet marketing chain through a series of field visits and focus group discussions with the stakeholders involved. We then compare the role of collective action in this new market with the case of marketing chains for cassava and organic pineapples, two cash crops with an expanding production in Kolli Hills. Our analysis shows the critical role of collective action and group initiative as a necessary but not sufficient condition for the successful commercialization of underutilized plant species for the benefit of the poor and the conservation of agrobiodiversity.
\end{abstract}

Keywords: Underutilized species, agricultural marketing, collective action, agrobiodiversity 


\section{TABLE OF CONTENTS}

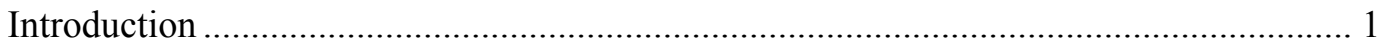

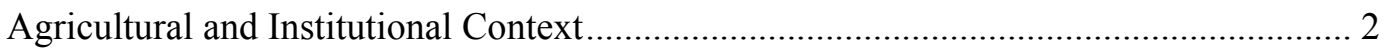

Collective Action and its Role in the Market .............................................................. 9

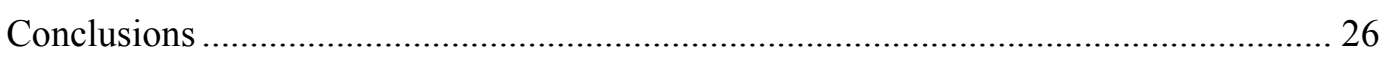

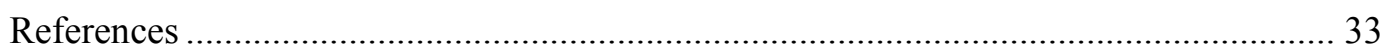




\title{
Collective Action and Marketing of Underutilized Plant Species: The Case of Minor Millets in Kolli Hills, Tamil Nadu, India
}

\author{
Guillaume P. Gruère, ${ }^{1}$ Latha Nagarajan, ${ }^{2}$ and E.D.I. Oliver King ${ }^{3}$
}

\section{INTRODUCTION}

Modern crop production is based on only a few plant species (Prescott-Allen and PrescottAllen 1990). However, many less well-known plant species continue to be grown, managed, or collected, particularly in rural areas of developing economies, thus contributing to the livelihoods of the poor and to agricultural biodiversity (FAO 2002). Some of these species, called underutilized plant species, are characterized by the fact that a) they are locally abundant in developing countries but globally rare; b) scientific information and knowledge about them is scant; and c) their current use is limited relative to their economic potential (Gruère et al. 2006). Most of these underutilized plant species can benefit from marketing development as a means to support their sustained use and help foster the conservation of agrobiodiversity, while generating sustainable income for the local producers and chain actors.

In South India, minor millets are examples of underutilized plant species, being locally important but commercially traded on a very limited scale outside the producing communities. Minor millets are often termed "coarse grains" and pertain here to finger millet, foxtail millet, and little millet. Furthermore, "minor" refers to the extent of research investment and commercial importance of the crop in terms of area, production, and consumption (Nagarajan and Smale 2005). In the Kolli hills of Tamil Nadu, a genetically diverse pool of minor millet varieties is grown by the tribal farming communities to meet their subsistence food needs. Most of these minor crops are not traded outside the farming communities, except on a very limited scale in the local markets as a result of a recent development intervention. Despite a consumption preference among the farming communities for minor millets, in the recent past the acreage under minor millet crops has declined considerably due to

\footnotetext{
${ }^{1}$ Guillaume Gruère, Environment and Production Technology Division, International Food Policy Research Institute, 2033 K Street, NW, Washington, DC, 20006 (g.gruere@cgiar.org)

${ }^{2}$ Latha Nagarajan, Environment and Production Technology Division, International Food Policy Research Institute, 2033 K Street, NW, Washington, DC, 20006 (1.nagarajan@cgiar.org)

${ }^{3}$ E.D. Israel Oliver King, Senior Scientist, M.S. Swaminathan Research Foundation, Namakkal Site Office, Namakkal 637 001, Tamil Nadu, India (mssrfnam@sancharnet.in; ediok151173@gmail.com)
} 
the availability of substitute crops such as cassava, rainfed rice, pineapple, and coffee, which are exclusively grown for market purposes. The M.S. Swaminathan Research Foundation, a leading non governmental organization that works on sustainable agriculture and development issues based at Chennai, India, has led targeted conservation cum commercialization intervention programs over the last 7-8 years in the Kolli hills, with the objectives of increasing the marketing potential of these minor millet crops by adding value to them and helping the farming communities to maintain the existing diversity among the minor millet crops by providing economic incentives for their conservation efforts (MSSRF 2002).

In this paper we provide an evaluation of the success of marketing development for minor millets in the Kolli Hills with a specific focus on collective action and group initiatives undertaken by the women's and men's self-help groups organized by the concerned non-governmental organization. We identify the key collective activities that are taking place in the minor millet value chain along with the major actors involved in it by conducting a series of field visits and focus group discussions with the stakeholders. Our main objectives are first to analyze the role of groups in the development and implementation of the marketing chain of minor millets, and second to study how this role compared to the case of markets for two other competing crops in the same area. Ultimately, our analysis intends to provide insights into the relative success of conservation cum commercialization interventions for the crops concerned.

The paper is organized as follows. We first present the context of the study, describing the agricultural system of Kolli Hills and the role and actions of M.S. Swaminathan Research Foundation in the area. We then analyze the nature and role of collective action initiatives that have been in operation in the development of the market for minor millets in Kolli Hills and compare them with collective action involved in the existing marketing channels for cassava and pineapple. Finally, based on the example of minor millets in Kolli Hills, we draw a few conclusions on the importance of collective action for the successful commercialization of underutilized crops and discuss the potential limits of market based solutions for the conservation of agrobiodiversity.

\section{AGRICULTURAL AND INSTITUTIONAL CONTEXT}

In this section, we present the geographical context and a description of the current agriculture system, and provide a short overview of the market development intervention in minor millets by the non-governmental organization M.S. Swaminathan Research Foundation. 


\section{Kolli Hills}

Kolli Hills (Kollimalai in Tamil) is a preserved mountainous area of the Eastern Ghats located on the eastern border of the Namakkal District of the Indian State of Tamil Nadu. Figure 1 provides a map of Kolli Hills and its relative location in India. The elevation of the central region of the hills ranges from just under $1,000 \mathrm{~m}$ to $1,350 \mathrm{~m}$ above mean sea level. Thanks to this elevation, the region benefits from relatively low temperatures in the area as compared to the remaining part of the state of Tamil Nadu: the maximum temperature ranges from $20-30^{\circ} \mathrm{C}$, while the minimum lie between 10 $20^{\circ} \mathrm{C}$. The average annual precipitation in the region is about $1,440 \mathrm{~mm}$, which also exceeds the State average (MSSRF 2002; Kumaran 2004).

Kolli Hills itself can be divided into two main physical components: the periphery and the central part. The periphery is covered with uninhabited preserved national forest lying on more or less steep slopes and largely contributes to the rich biological diversity attributed to the region. The central part is inhabited and is covered mostly by agricultural or agro-forestry area, as a replacement to what used to be only forests. Overall, according to Kumaran (2004), forests occupy 44 percent of the total area of 28,293 ha, while agricultural activities take place in 52 percent of the area, leaving 5 percent for other activities. 
Figure 1. Map of Kolli Hills

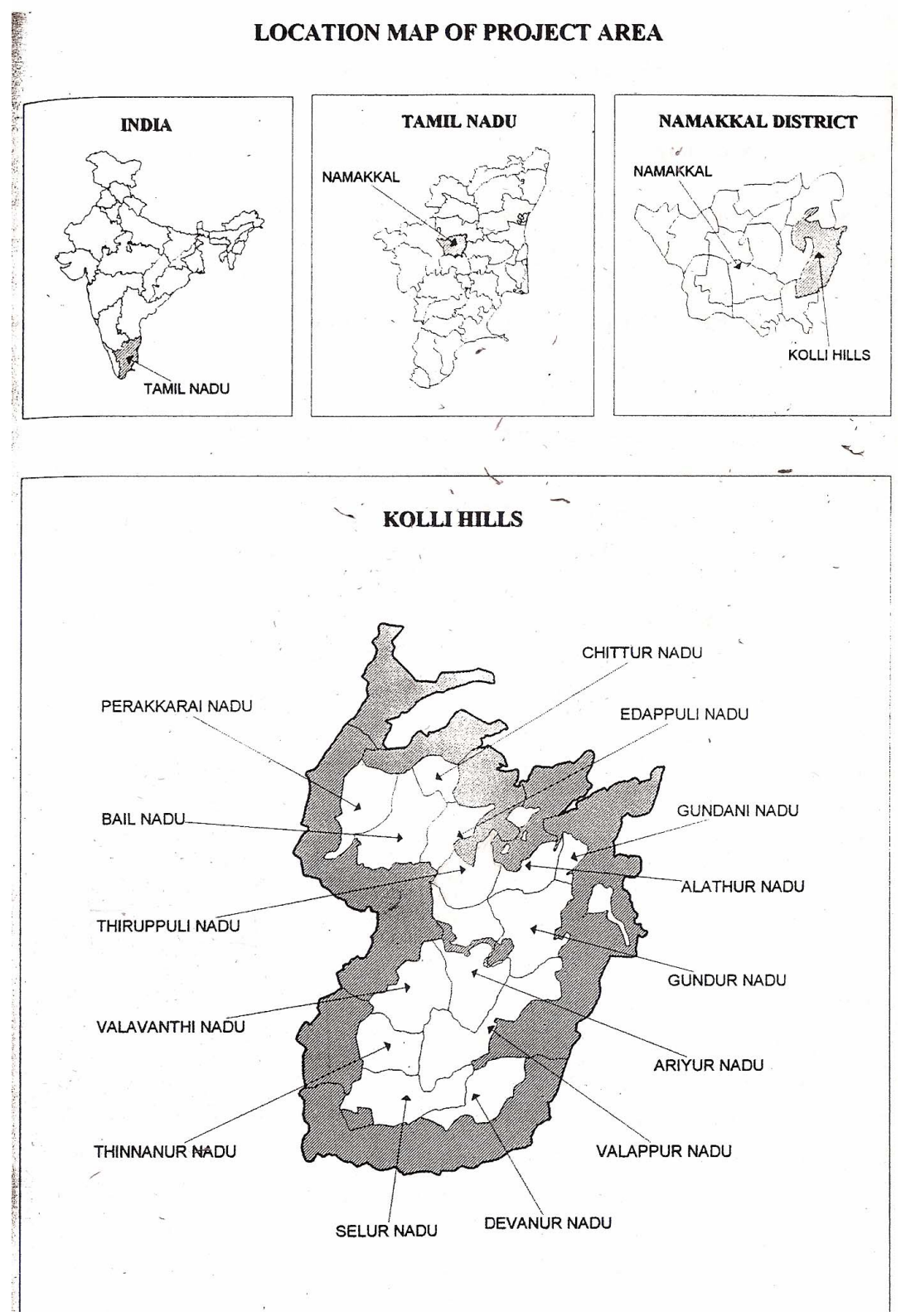

Source: Kumaran (2004)

The estimated 50,000 population of the Kolli Hills is distributed in fourteen administrative village clusters (nadus ${ }^{4}$ or panchayats) as indicated on the lower map of Figure 1. More than 95

${ }^{4}$ Nadus are historic classification of villages since the medieval period. In these 14 nadus, there are 16 revenue villages and 263 hamlets. Normally a nadu refers to a village community comprising 10-15 settlements, which was later redesignated as panchayats by the government of Tamil Nadu. 
percent of the inhabitants are tribal people from the Mayali community (MSSRF 2002). The whole region is linked to the rest of the Namakkal district by only one paved road on the South west of the Hills that leads to the hamlet of Semmedu in the Valavanthi nadu. Semmedu is also where the governmental departments are located, including the education and primary health offices for the whole region. As a result, inhabitants have to travel to Semmedu on many occasions. There is only one secondary school in Kolli Hills, located at Semmedu. The local literacy rate in the Hills is about 31 percent, while female literacy rate is only 23 percent (Pradeep and Rajasekeran 2006). There is no hospital, and infant mortality is 30 percent. There are no transportation means in several parts of the Hills, so people have to walk from place to place. Roads cover a large part of the area, but some hamlets remain isolated from any road infrastructure. Every village is led by a Gounder (the village head man), which supervises the panchayat president.

\section{Minor Millet and Other Crops}

Historically, the Hills were covered with pristine forests and inhabited by nomadic tribes that would change their settlement from year to year. In the last 30 years, forest has been quickly replaced by cultivated land, prompting the State government to protect the boundary forest to avoid a complete depletion of the forest ecosystem. At the same time, the deforestation led to stable settlement of the tribes in the central area of the Hills. Despite the almost complete depletion of the forest in the central area, certain patches of forests have persisted due to the will of inhabitants to voluntarily preserve them as sacred groves. Currently, the State forest service inspects the boundary of the central area to enforce the strict conservation, but despite their efforts, the arable land is slowly expanding from year to year. Because of the recent past of this forest area, most land in the central area is covered with red soils that are rich in bauxite and other minerals, and allow for a number of crops to thrive.

The land is now divided into different strata, which also correspond to their respective uses. Kumaran (2004) classifies land used for agriculture in Kolli Hills into three types: first, the land in the valleys with springs, primarily used for the cultivation of wet land crops such as paddy; second, the dry lands with rainfed cultivated land allocated mainly for growing millets and cassava; and third, the land on the fringes of the valleys devoted to the cultivation of pineapple, coffee, pepper and other condiments. In recent years, the dry lands have quickly been shifted to the cultivation of cassava only. Pradeep and Rajasekeran (2006) estimate that cassava land now represents about 75 percent of the total dry lands. Overall, irrigation facilities are available to less than 15 percent of the area through springs and wells; the remainder is rain-fed (MSSRF 2002). To show the diversity of the agricultural 
landscape, we represent the cropping pattern as seen in Padasolai, one of the typical settlements in Kolli Hills, in Figure 2.

Figure 2. Schematic representation of the agricultural pattern in Padasolai settlement, Kolli Hills (August 2006)

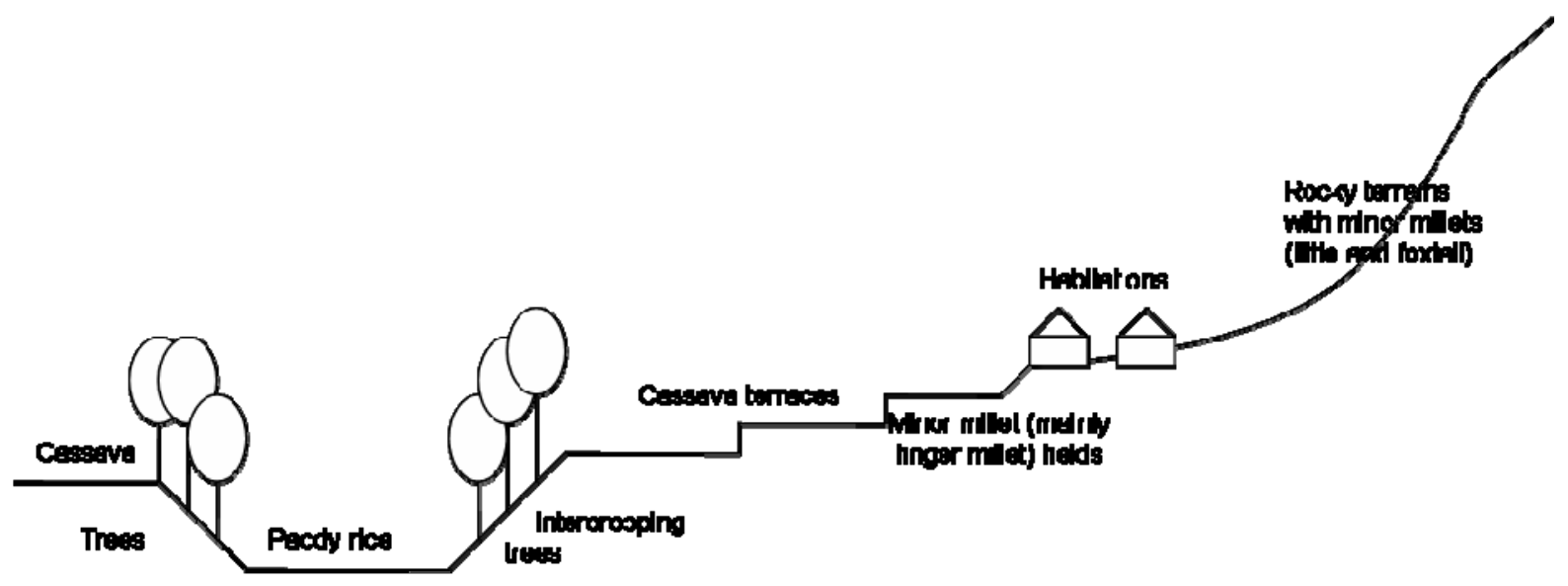

In this representative village, the landscape is terraced, with rice at the bottom of the valleys, above which are located several terraces of cassava in well prepared terrains, followed by a small area devoted to minor millets (mainly finger millets). Above the inhabited areas, other minor millets are sparsely sown into rocky terrains on the upper part of the slopes. Multi-cropping patterns with coffee, banana, pepper (inter cropped with silver oak trees, especially for taming peppers), cardamom, guava, and jackfruit occupy the interspaces between levels.

The Kolli Hills are known for agrobiodiversity and especially the genetic diversity in minor millets. In the context of the Hills, the term "minor millet" refers to little millets (Panicum milliaceum), finger millets (Eleucine corocona), and Italian millets (Setaria italica). Each of these crop species presents a diversity of land races. The intra-specific phenotypic variability of minor millets is enormous; the populations are highly heterogeneous in morphological and agronomical character. The heterogeneity within the races and the microclimatic variations in the fields at different altitudes help reduce the risk of crop loss due to various abiotic and biotic stresses. The region is also known for its knowledge of traditional (indigenous) medicine and for their honey extraction because of the high flavor and quality.

In Kolli Hills, as in other places of India, minor millets were grown extensively and consumed widely. The traditional agricultural system primarily comprised of growing minor millets 
(mainly as a mixed crop) in the existing forest ecosystem with no tillage and no external inputs. The system was highly subsistence-driven in nature. But their cultivation has declined due to changing consumption and production preferences, and the increasing presence of competing crops such as rice, cotton, and other cash crops. Historically, minor millet production in Kolli Hills started declining from the mid 1980's in the Hills and was progressively replaced by cassava (tapioca), a cash crop, since the early 1990s. Table 1 shows the increasing dominance of cash crops, cassava, and pineapple over traditional crops in the region. The area devoted to minor millets decreased from 4,200 ha in 1960 down to about 1,000 ha in 1997. Meanwhile, cassava and pineapple were not cultivated in 1960s and quickly expanded after their introduction to reach an estimated total of 5,900 ha by 1997 (Nagarajan 2000). 
Table 1. Evolution of the acreage devoted to minor millets, cassava and pineapple

\begin{tabular}{llll}
\hline Year & Minor Millets (ha) & Cassava (ha) & Pineapple (ha) \\
\hline 1970 & 1799 & 0 & 40 \\
1995 & 950 & 2020 & 740 \\
1997 & $967^{*}$ & $5000^{*}$ & 900 (est.) \\
\hline
\end{tabular}

Source: Compiled by the authors based on the handbook of statistics of Tamil Nadu 1997 and other sources. * MSSRF (2002).

Like most other crops currently cultivated in the Hills, cassava is an exotic crop for the area and was completely unknown to the local population before its introduction. Minor millets are probably among the last traditional crops in the Hills, along with certain medicinal plants that also remain largely underutilized. The shift to cassava was generated by an increasing demand from starch-based industries located in the plains of the Namakkal and Salem districts, particularly for the production of sago, the most popular starch product. Most local cassava processing companies located in the plains offer attractive contract-farming arrangements to local producers, in which they provide the necessary agricultural inputs and assure yearlong remunerations to farmers.

\section{Role of M.S Swaminathan Research Foundation}

The M.S. Swaminathan Research Foundation (MSSRF) is a very reputed non-governmental organization, founded and led by the eminent agricultural scientist, Professor M.S. Swaminathan, headquartered in Chennai, the capital city of the State of Tamil Nadu. The MSSRF conducts research and development projects on agriculture and conservation based issues in certain regions of rural India. The strategy formulated by the foundation is fundamentally demand-driven; all interventions are preceded by series of consultations with the concerned stakeholders. The foundation also strongly believes in the role of collective action among rural communities as a driver for any sustainable initiative.

In Kolli Hills, the MSSRF started its intervention in 1994, by conducting a three-year appraisal of the issues faced by farmers of minor millets and other crops in the area. At the end of the process, several issues were identified: the decline in the food basket, land transformation towards irrigated cassava cultivation, and the lack of marketing system for minor millets. Before the MSSRF intervention, there was no marketing system for food derived from minor millets in Kolli Hills, except in the case of finger millets, which are widely known and used as a food substitute for diabetics.

These audits led to several subsequent programs over the nine years. First, the MSSRF devised certain field based value addition activities in food fortification among minor millet growers in Kolli Hills. Second, a program was initiated to promote millet biodiversity by means of 
conservation and commercialization. In this latter program, the MSSRF identified three main objectives: productivity improvement, improvement of millet quality, and facilitation of processing of minor millets.

To address these issues, the MSSRF initiative first proposed to work on marketing chain improvements. The foundation set up a field based station in the Hills with the objective of demonstrating the potential of improved agronomic practices on minor millet crops productivity as well as to begin training on post-harvest handling methods. More specifically, the MSSRF established seed banks and initiated a participatory plant breeding effort on minor millets. The selection of lines from a pool including the traditional varieties and improved varieties obtained from ICRISAT was made by minor millet users and producers with the objective of conservation and productivity improvement to obtain a large portfolio of adapted varieties. On the supply chain, the objective of the foundation was first to link the primary producers to a marketing chain; second, to develop different uses of the minor millets; and third, to promote it as a competitive alternative to other cereal crops. Finally, the MSSRF has also been involved in a program providing enterprise management skills and knowledge of supply system along the chain. The capacity building strategy followed a trainers training methodology for rapid replication of skills and knowledge dissemination among the communities. Most of these programs were carried out with the major funding from the SDC (Swiss Development Agency) and the IFAD (International Fund for Agricultural Development).

\section{COLLECTIVE ACTION AND ITS ROLE IN THE MARKET}

\section{Self-Help Groups and Enterprises}

Until recently, minor millets had been cultivated on a subsistence scale, and marketing was considered the main constraint for scaling up the production. The MSSRF established market linkages at the local and regional levels. To do so, self-help groups and enterprises were formed to institutionalize market operations. The various groups have also been brought under a single system of federation that was linked to the Tribal Cooperative Marketing Development Federation of India Ltd. (TRIFED). Marketing mechanisms and particular economic linkages were negotiated and resulted in a Memorandum of Understanding stating the rules and procedures to be followed by marketing federation members. It was signed by representatives of each group (MSSRF 2002). 


\section{Self-help groups}

Self-Help Groups (SHGs) are the common grass root institutions through which development activities are implemented in many regions of India. The participation is voluntary, and the basic schemes are based on internal lending incentives. These groups meet every other week to discuss current issues and put together their own funds. Originally, these groups were promoted as a means for families to help each other financially. In 1996-1997 thirteen self-help groups (SHGs) were created as part of the participatory rural appraisal of the MSSRF.

Over the last seven years, the MSSRF has helped with forming 36 self-help groups in 35 village settlements in Kolli Hills. The MSSRF acts as an initial catalyst of these groups: helping them to organize themselves; training them in financial as well as book keeping skills; imparting skills to take up enterprise based activities; assisting them in getting financial help from the financial institutions; and then following up periodically to evaluate their functioning, especially during the incubation period. However, the work division and the group meetings are organized and sustained according to the choice of the village participants.

All these self-help groups are governed by certain rules and regulations in order to ensure the smooth operations with in the group activities. Moreover, since the groups are linked to financial institutions (banks), they have some prescribed procedures to meet certain financial obligations in order to qualify for loans. The size of SHGs ranges from 11 to 20 members. Most of these SHGs are comprised exclusively of male or female members of the community; only a few groups are mixed with the participation of both male and female members.

\section{Enterprises}

As part of the development of market for minor millets, as well as other initiatives taken in the valley on pineapple marketing and seed conservation efforts, a number of specific task driven groups were formed based on the choice of people in the concerned communities along with the feasibility of the proposed enterprises. These enterprises, such as the ones that contribute to the marketing of minor millets, undertake various activities from input and seed conservation (seed packaging) to packaging of processed millet products. Each enterprise is comprised of people belonging to one or more SHGs. The basic infrastructure for each of these enterprises was either funded voluntarily by village participants or provided with the help of MSSRF grants and loans, and in one specific case funding obtained by the enterprise from the State of Tamil Nadu. 
Table 2. Characteristics of enterprise groups in Kolli Hills

\begin{tabular}{|c|c|c|c|c|c|}
\hline SNO & Group type & $\begin{array}{c}\text { Total } \\
\text { Members }\end{array}$ & Men & Women & $\begin{array}{l}\text { Enterprise } \\
\text { selection }\end{array}$ \\
\hline 1 & Men & 12 & 12 & 0 & $\begin{array}{l}\text { Rice and Millets } \\
\text { dehusking mill \& } \\
\text { marketing }\end{array}$ \\
\hline 2 & Women & 12 & 0 & 12 & Organic Pineapple \\
\hline 3 & Women & 12 & 0 & 12 & Millets marketing \\
\hline 4 & Women & 12 & 0 & 12 & Millets marketing \\
\hline 5 & Women & 18 & 0 & 18 & organic pineapple \\
\hline 6 & Women & 13 & 0 & 13 & $\begin{array}{l}\text { organic pineapple, } \\
\text { Ragi Flour mill }\end{array}$ \\
\hline 7 & Women & 20 & 0 & 20 & organic pineapple \\
\hline 8 & Women & 19 & 0 & 19 & $\begin{array}{l}\text { organic pineapple, } \\
\text { Ragi Flour mill }\end{array}$ \\
\hline 9 & Mixed & 13 & 10 & 3 & Millets marketing \\
\hline 10 & Mixed & 14 & 8 & 6 & organic pineapple \\
\hline 11 & Mixed & 12 & 5 & 7 & Millets marketing \\
\hline 12 & Men & 13 & 13 & 0 & $\begin{array}{l}\text { Rice and millets } \\
\text { dehusking mill }\end{array}$ \\
\hline
\end{tabular}

Source: Compiled by MSSRF field staff at Kolli Hills in 2006

Out of the total 36 groups formed by MSSRF in Kolli Hills, 12 groups are involved in millets and pineapple processing and trading activities by participating in markets. Table 2 summarizes briefly the characteristics of these enterprise groups involved in millets and pineapple activities in Kolli Hills. Like individual SHGs, enterprises comprise of 11 to 20 members. There are men's groups, women's groups, and mixed groups. Membership in an enterprise is decided by the community and individual farmers. At the same time, there is no entry fee: therefore, the poorest members of the community can join. The only condition is that members should be farmers that grow one of the targeted crops. Interestingly, the size of the group depends on the choice of the enterprise. In the case of dehusking/milling groups (presented in the next section), the preferred size of the group is 20 , as most of the activities done by these groups are mechanized, so increasing the size of the group would not add to the scale of the operation. The size also matters in managing the operations efficiently. Any group that exceeds 30 members had both operational and administrative issues. Among enterprises, there are male groups, female groups, and mixed groups, based on the decision of each enterprise's original founders. Members tend to be from the same village or settlement and mostly belong to a single clan/caste. 
A map of the different enterprises in the Hills is provided in Figure 3. Twelve types of enterprises were set up with specific activities ranging from agronomic input groups (seed banks) to credit institutions (mainly micro credit), marketing, and processing groups. All these collective activities initiated by the MSSRF are based on promoting conservation efforts and creating markets and infrastructure, along with commercialization. As shown in Figure 3, these enterprises are spread out all over the Hills. More generally, a map of SHGs, also set up by Kumaran (2004), shows that the MSSRF intervention covered most of the crucial point for the successful marketing of minor millets. We describe the role of each enterprise involved in the market chain of minor millets in greater detail in the following section.

Figure 3. Map of enterprises in Kolli Hills.

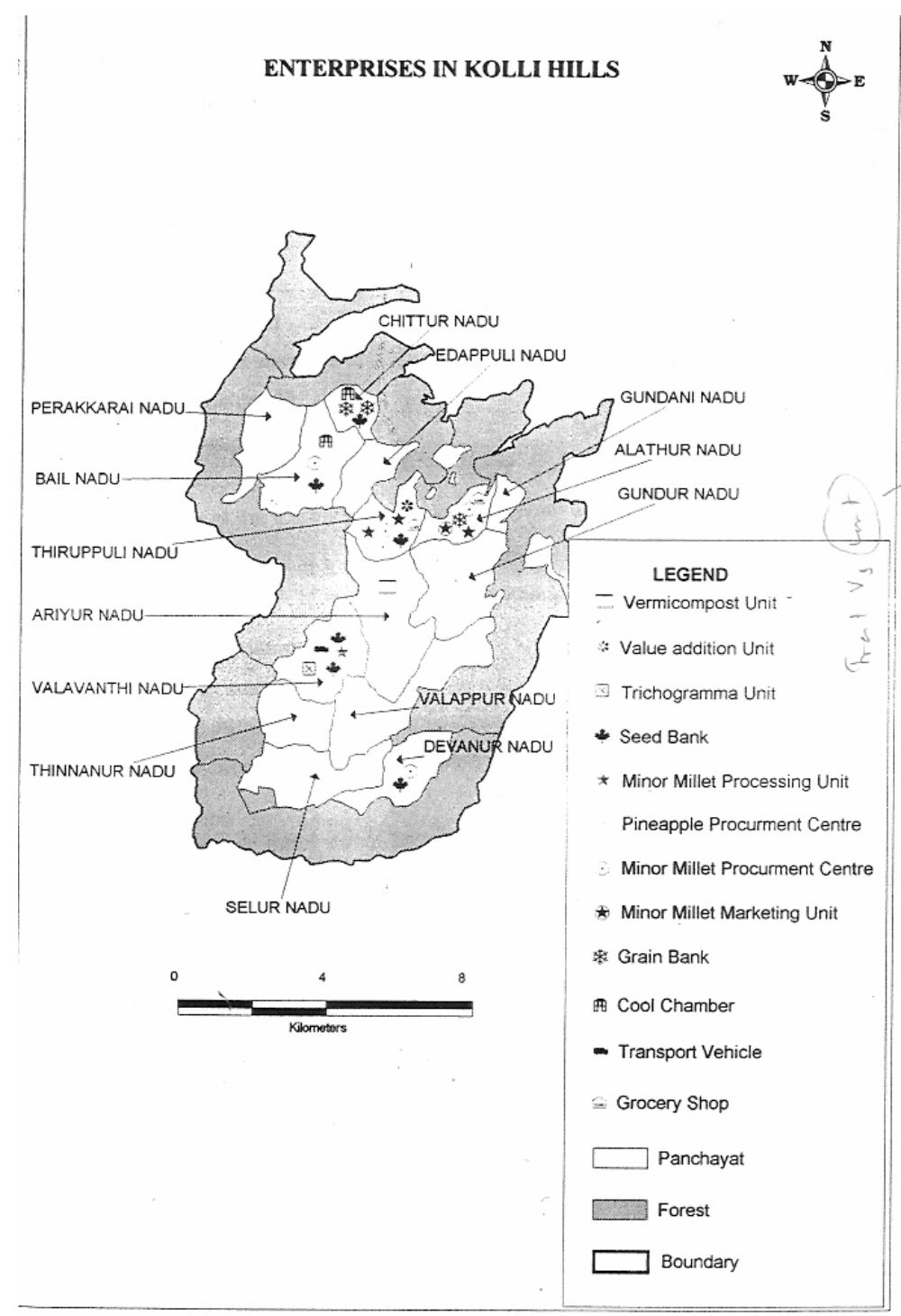

Source: Kumaran (2004) 


\section{Market Chain of Minor Millets: From Group to Group}

In this section we provide a description of the market chain for minor millets in Kolli Hills as it currently stands and then focus on three specific groups of market actors to understand the role of these groups in the market chain.

\section{Description of the overall market chain}

The supply market chain for minor millet involves three major types of groups: 1) a first group in charge of procuring millet from farmers; 2) a second SHG in charge of dehusking and processing; and 3) a third set of SHGs to take care of value addition packaging before sending the products to retailers. In addition, a number of other groups contribute to activities related to input and production of minor millet. The complete marketing channel is represented in Figure 4. At the end of the chain, minor millets are now sold packaged as "ready to cook" grain, flour, or malt to local consumers, and recently to a few supermarkets in Chennai (Spencer's).

We show a detailed distribution of marketing margins and cost additions in Table $3 .{ }^{5}$ Prices and marketing margins were set up in agreement with all groups when setting up the memorandum of understanding and remain constant per unit. They reflect the cost of the transaction. The retail price of products derived from minor millets is currently around Rs. 18-20/500g packet of clean millet rice. Of this amount, farmers get approximately Rs. 6; the procurement group gets Rs.1.50; the processing group gets Rs. 1.25; transport gets Rs. 0.60; value addition units use Rs. 3.25, with transport Rs. 1.502.50 to sell it to the retailer which keeps a margin of Rs. 4-5. Thus, primary producers keep about 30 percent of total retail price which is more than reasonable as compared to other processed food products. Currently the demand is more than sufficient, and most of it comes from metropolitan regions with health conscious consumers and diabetics. Generally, local MSSRF staff believes that the market potential is relatively small but could grow in the near future.

\footnotetext{
${ }^{5}$ The numbers in Table 3 are reported in Rps per kilogram of grain until the processing stage. After this stage, the numbers reported reflect Rps per kilogram of processed product.
} 
Figure 4. Schematic representation of the market chain for minor millets

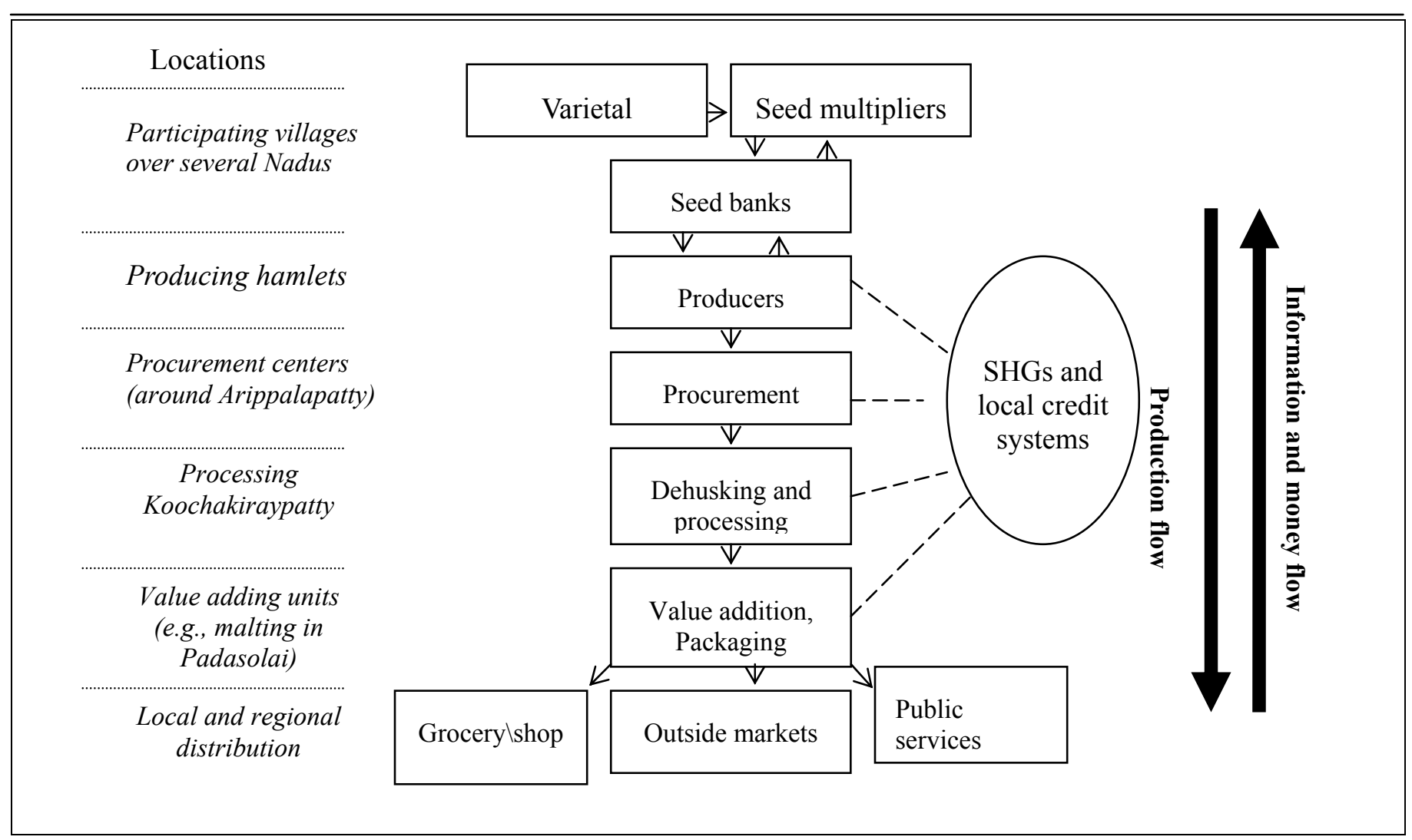


Table 3. Margins received by the enterprise groups for processed millets in Kolli Hills

\section{Stage in marketing Marketing margin Add up costs chain}

\begin{tabular}{|c|c|c|c|}
\hline $\begin{array}{l}\text { Procurement price at the } \\
\text { farm gate }\end{array}$ & Rs. 6/kg & Rs 6/kg & $\begin{array}{l}\text { Little and fox-tail millets are procured at } \\
\text { this rate. Finger millet is procured at Rs. } 9 \\
\text { per kg because of higher demand from the } \\
\text { buyers. }\end{array}$ \\
\hline $\begin{array}{l}\text { Procurement and } \\
\text { transportation to the } \\
\text { processing center }\end{array}$ & Rs. 1.50 per $\mathrm{kg}$ & Rs $7.50 / \mathrm{kg}$ & \multirow[t]{2}{*}{$\begin{array}{l}\text { Currently, the procurement group hires a } \\
\text { van for transportation to the dehusking } \\
\text { center situated } 8-9 \mathrm{kms} \text { away. }\end{array}$} \\
\hline $\begin{array}{l}\text { Processing and/or } \\
\text { dehusking at the mill }\end{array}$ & Rs. 1.25 per $\mathrm{kg}$ & Rs $8.75 / \mathrm{kg}$ & \\
\hline $\begin{array}{l}\text { Transportation to value- } \\
\text { addition center }\end{array}$ & Rs. 1.25 per kg * & Rs $10 / \mathrm{kg}^{*}$ & $\begin{array}{l}\text { Value addition centers are located in } \\
\text { different village communities }\end{array}$ \\
\hline \multicolumn{3}{|l|}{ Value addition } & \multirow{3}{*}{$\begin{array}{l}\text { Value addition centers managed by groups } \\
\text { involved i) in breaking the dehusked } \\
\text { grains as rice, which is cleaned, and } \\
\text { packed for sale as whole or broken grains } \\
\text { in the market, including recipe pamphlets; } \\
\text { or ii) malt making by further grinding and } \\
\text { including other ingredients, such as wheat, } \\
\text { maize, cardamom and green gram }\end{array}$} \\
\hline $\begin{array}{l}\text { i) Value addition as } \\
\text { polished and cleaned rice }\end{array}$ & $\begin{array}{l}\text { i) Rs. } 1.50 / \mathrm{kg}^{*} \text { for } \\
\text { cleaning }+ \text { Rs. } 5 / \mathrm{kg}^{*} \\
\text { for packing }\end{array}$ & Rs $16.50 / \mathrm{kg}^{*}$ & \\
\hline $\begin{array}{l}\text { ii) Value addition } \\
\text { through malt making }\end{array}$ & $\begin{array}{l}\text { ii) Rs. } 5 / \mathrm{kg}^{*} \text { of malt }+ \\
\text { packing cost of Rs. } \\
2 / \mathrm{kg}^{*}\end{array}$ & Rs $17 / \mathrm{kg}^{*}$ & \\
\hline \multirow{2}{*}{$\begin{array}{l}\text { Transportation to } \\
\text { retailers }\end{array}$} & & & \multirow[t]{6}{*}{ Normally sent in bulk to reduce the cost. } \\
\hline & a) Rs. $3-5$ per $\mathrm{kg}$ * & Rs $22 / \mathrm{kg}^{*}$ & \\
\hline \multirow{2}{*}{$\begin{array}{l}\text { a) To local markets in } \\
\text { plains } \\
\text { b) To Chennai }\end{array}$} & \multirow[t]{2}{*}{ b) Rs. $10-12$ per $\mathrm{kg}^{*}$} & \multirow[t]{2}{*}{ Rs $27-30 / \mathrm{kg}^{*}$} & \\
\hline & & & \\
\hline \multirow[t]{2}{*}{ Retail } & $\begin{array}{l}\text { 1. Namakkal and the } \\
\text { plains- Rs. } 8 / \mathrm{kg} .^{*}\end{array}$ & Rs 30/kg* & \\
\hline & $\begin{array}{l}\text { 2. Chennai: Rs.10/ } \\
\text { kg.* }\end{array}$ & Rs $42 / \mathrm{kg} *$ & \\
\hline
\end{tabular}

\footnotetext{
${ }^{*} \mathrm{Kg}$ of processed products, knowing that the processing rate is about $1: 1.5$, i.e., about $50 \%$ of unprocessed millet is lost.

Source: Compiled based on authors' own data.

As explained in the next few sections and shown in Table 2, many activities in the minor millet commercialization are led by men's or women's groups. Rengalakshmi et al. (2006) provide an analysis of gender roles and decision-making in minor millet cultivation and utilization, to illustrate how women's role is linked to the cultivation of subsistence food crops. Both men and women take part in the crop and land race selection process. They also jointly decide on the allocation of area for cultivation under different crops on their land. Men exclusively perform activities like plowing, seed sowing, and cross-plowing, to carry out weeding and thinning of excessive seedlings. While men and women jointly decide the suitable time for sowing, only women decide the suitable time for cross-
} 
plowing (due to their close observations of crop growth) as well as many other vital activities like maintaining optimum population, weeding, and continuous monitoring and seed management. However, men are often also involved in weeding if labor is inadequate, though this task is expected to be done exclusively by women. Both men and women do harvesting, threshing, winnowing, and packing. ${ }^{6}$

\section{Marketing strategy}

Currently the focus of MSSF is to try to establish a robust local market - within 100km radius - by using promotion campaign, awareness, and new recipes in order to add value locally. To expand demand, a branding strategy was adopted to try to better promote the product as locally grown and organic due to the chemical free production practices used in the Hills. Two types of packages are sold with recipes and pieces of advice on how to use the products, both in Tamil and in English. The provided recipes come from traditional uses and new uses developed by cooking specialists. For example, women from the SHG in Arippalapatty reported that they have traditional recipes using finger millets or Italian millet (porridge).

The groups have also compiled a recipe booklet on minor millets (MSSRF 2004), which is sold as a part of the marketing effort. The major task of the market developers and the remaining challenge for the MSSRF is to raise awareness in order to increase the share of households likely to consume minor millets. To do so, MSSRF staff has used local events and the annual temple festival in Semmedu and Arapalleswarar temples to sell the products made from minor millets and inform the plain visitors about the various recipes and the nutritional quality of the millets. For instance, MSSRF field staff in Namakkal/Kolli Hills organized an exhibition (Aug 1-3 ${ }^{\text {rd }}, 2006$ ) at the annual temple festival in Kolli Hills, held by the Tamil Nadu State Tourism Development Corporation. The purpose was to demonstrate the various culinary preparations made from minor millets in order to promote the concept that minor millets are health foods. The farmers groups sold different minor millet products during the exhibition and netted a profit of around Rs.4500 (100 USD). Out of 40 exhibits, this theme was selected as one of the best displayed, and the Ministry of Tourism and Development, Government of Tamil Nadu awarded it first prize.

At the same time, the MSSRF wants to go further through policy advocacy. When we visited the hamlet of Padasolai, a settlement where finger millet is grown primarily for malt making purposes, we were able to visit a kindergarten facility run by the government that provides free meals twice a week to young children. As part of the statewide program entitled the Integrated Child

\footnotetext{
${ }^{6}$ For more information, see Rengalakshmi et al. (2006).
} 
Development Services (ICDS), prepared meals are provided with proper nutritional content, which include wheat, maize, sorghum, finger millet, and other minor ingredients. The foundation is trying to promote the use of all types of minor millets into noon meal schemes to further increase demand. In parallel, the Foundation is also lobbying the federal government to include minor millets in other child programs. Swaminathan (2006) recently urged the government to permanently require the purchase and inclusion of ragi (finger millet), bajra (pearl millet), jowar (sorghum), and other millets in the public distribution system (PDS) in order to ensure nutrition security and production sustainability. He further emphasized that these underutilized crops should be referred as 'nutritious cereals' instead of 'coarse cereals' as currently done.

The major challenge on the consumption side comes from the fact that most other crops, and particularly close substitutes, are heavily subsidized both on the production and consumption side, when millets are obviously not targeted by any government program. For instance, there is a consumption quota of rice provided to each family every month for a very low and insignificant price.

\section{Participatory varietal selection site in Padasolai}

On the productivity side, the MSSRF has employed two distinct strategies for productivity improvement: first, improved cultivar selection, and second, extension to improve agronomic practices with line sowing and proper spacing.

One of the major activities undertaken by the foundation was to conduct a selection of minor millet cultivars and varieties. This process started with the provision of up to 2000 isogenic lines that were then progressively reduced to 36 lines. The original 2000 lines included both the land races of the Kolli Hills and improved cultivars from various research institutions obtained from the International Crops Research Institute for the Semi-Arid Tropics (ICRISAT). The selection was done using a participatory approach with the help of voluntary farmers. SHGs of farmers were able to compare the output of different varieties and make their choice according to their own criteria. They chose improved varieties as well as certain local land races. This mixed outcome is seen as very positive from the point of view of the MSSRF whose goal is to increase productivity for marketing while maintaining traditional lines to conserve local diversity. New improved varieties have shown a potential yield improvement of 10-20 percent compared to traditional ones. The yield could improve from $2400 \mathrm{~kg} / \mathrm{ha}$ to $2700 \mathrm{~kg} / \mathrm{ha}$.

Tribal women played an essential role in this participatory plant breeding experiment (MSSRF 2002). Thanks to their practical knowledge in seed selection, they assured that the selection approach was balanced. For instance, little millet land races were selected by a set of men and women, but their selection criteria varied greatly. The men selected early maturing variety while the 
women preferred varieties with high yield performance or nutritious quality. The women, being responsible for cooking, preferred varieties with adequate taste and consistency; they also considered the vigor of the whole plant in the marginal agro-ecosystem along with well filled grains in the panicle, while men used 'good panicle' as their main choice variable (MSSRF 2002).

We visited the hamlet of Padasolai, which was one of the locations where seed multiplication was going to be conducted for several selected improved lines of minor millets. Figure 2 represents the cropping pattern during our visit at the beginning of August 2006, which took place during sowing time. We met with the local landowners and farmers preparing the soil and sowing seeds, as well as local helpers that are managing the seed multiplication stage of the process. Although farmers and landowners who take part in this multiplication are voluntary participants, the seeds produced with multiplication will be partly sold to the MSSRF for distribution to farmers and partly kept by the landowners for their own use. Helpers come to provide support and extension advice particularly during the critical multiplication stage, but after that the farmers will be on their own.

To summarize, the seed selection and multiplication activity included two types of group: the SHGs that selected the lines and the group of helpers (who are also farmers) that voluntarily provided the seed and organized the seed multiplication process. These groups helped with convincing and supporting the local producers and landowners who devote some of their land to multiplication on a semi-voluntary basis.

\section{Women's group on procurement of minor millets in Arippalapatty}

To observe and analyze collective action on the lower level of the marketing chain of minor millets, we held a discussion with a women's group from Arippalpatty. The women in this group are primarily responsible for procuring minor millets in and around growing regions and then transporting them to the dehusking center for further processing and marketing. Group members say that they produce about $300 \mathrm{~kg} /$ household, out of which they keep 50 percent for home consumption and sell 50 percent for processing. Most farmers keep their own seeds for the next season; they sow with 50 percent old and 50 percent new seeds. To procure the grains, group members walk up to 5$7 \mathrm{~km}$ and transport millets on head loads or sometimes by bus. Then they gather all grain in an assembly room and hire a vehicle to transport the harvest to the Koochakirayanpatty processing mill. The transportation costs Rs. 500 per ton of minor millets.

Their marketing margin is fixed at Rs. $1.50 / \mathrm{kg}$ : they procure unprocessed minor millets from farmers at the rate of Rs. $6 / \mathrm{kg}$, and processing pays Rs. $7.50 / \mathrm{kg}$. As for information transmission, group members think that the current system is working efficiently among the various groups. Information about demand is provided before harvest from the end of the chain, and then they procure 
adequately to meet the demand. During the previous year, $1,000 \mathrm{~kg}$ of packaged product was obtained in this particular location. The procurement system starts locally and then expands to other villages, when each participant of the procurement group goes door to door to ask inhabitants if they have millet to sell. They go on until they obtain the total required demand. The total production capacity is uncertain, but they believe that the supply could be easily doubled in their area.

In fact, the problem is not with the quantity, but more with the production area. The Hills agricultural system is dynamic, and it progressively pushes minor millet towards the top of the hills as time passes by. The cycle goes as follows: 1) fields are covered by weeds; 2) producers burn the weeds; 3) they cultivate millets for two years; 4) they flatten the land; 5) they plant cassava; 6) after a number of seasons of cultivating cassava on the same land the soil becomes unfertile; and 7) tree plantation and fallow replace cassava, and then the field could go back to the first step. The risk seen by the MSSRF is that minor millets will continue to be marginalized to finally be dropped off the system in favor of profitable cash crops that have no subsistence value and tend to deplete the fertility of the soil when cultivated intensively.

\section{Dehusking and processing mill's men's group of Koochakirayanpatty}

Further along the marketing chain, we also interviewed members of the SHG who manage the dehusking and processing facility in Koochakirayanpatty. We met with three members of the men's self-help group at the processing facility. The group includes twelve members, but with a rotation of the "on duty call" for carrying out and managing mill operations, only two members work there every day, with the help of assistants. They process rice and millets and charge Rs. $1 / \mathrm{kg}$ of raw minor millet processed.

The major challenge for this group was obtaining the necessary infrastructure, which included machinery and a building, and meeting the energy requirements. They first obtained a loan from the MSSRF to purchase machinery and purchased the land to set up the facility. Then they complied with governmental standards and fulfilled all regulatory requirements. In return, they obtained a special grant from the District Rural Development Authority (DRDA), which amounted to Rs.37,000 to construct the building. This type of grant is rather exceptional, and this can be considered an enormous achievement. At present, they have the personnel, the machines, and the building, and they are waiting to be connected to electricity in order to replace the current diesel engines in the near future.

Like other enterprises, this group is working in agreement with other groups and in constant contact with other actors of the chain. In particular, they take part in discussions with groups lower and higher in the marketing chain to set up the production numbers, collaborate on the financial side 
to pay the procurement group at the rate of Rs. $7.5 / \mathrm{kg}$ of raw product, and receive payments from the marketing and packaging group in exchange for the dehusked and/or milled flour from minor millets.

In the following section, we present the case of other crops in the Kolli Hills area as a basis for comparison of the role of collective action in markets for underutilized species.

\section{Collective Action and Marketing of Pineapples and Cassava}

\section{Market improvement and organic certification of pineapples}

Pineapples produced in the Kolli Hills have a reputation for their freshness and taste. During the consultation by the MSSRF, five villages with a large area under pineapple cultivation were selected and mobilized into five self-help groups (three women's groups, one men's group, and one mixed group). One of the issues that came to the forefront was the difficulty of communities to transport pineapples to the market. Many pineapple producers had to walk all night before the market day with heavy loads to access the regional market in Kolli Hills due to the long distance between production sites (which tend to be high in the fringe of the valley) and market sites which are located near Solakaddu, to facilitate the access of traders coming from the plains. As a response, the MSSRF, as part of a project funded by the International Development Research Centre (IDRC), together with the producing communities, helped to organize procurement self-help group for pineapples, in order to simplify transportation. It was decided to set up procurement centers very close to production areas and use them as a starting point for truck or vehicle loads carrying pineapples to the central market.

The second intervention of the MSSRF was designed to help set up an association of producers of pineapples and to link this group to an exporter of organic pineapples, the Ionic Exchanges India Ltd. (IEEFL). Since Kolli Hills producers benefit from very good conditions and low pest infestation, they do not need to use any type of chemical control, provided that good agronomic practices are used, and could, therefore, obtain organic certification without much effort. ECOCERT International, a German organic certification company, was approached for certification. A group of multi-disciplinary experts inspected the site and certified an area of 232 acres as an organic production zone for pineapple cultivation.

The main issue faced by producers is the payment of the organic certification costs. As in other cases, the intervention was progressive: first, the MSSRF entirely paid the certification costs in the initial year; then the local association of producers paid 50 percent based on their revenue of the first year; and during the third season they paid all the certification costs. Certification costs are quite high; they include annual inspection of fields, markets, transport, and wholesale by the German-based ECOCERT. But the association of producers rapidly saw that it was worth the cost as the pineapples 
that were usually sold for Rs. $1-3 / \mathrm{kg}$ are now sold to exporters for Rs.5-6/kg, for an average increase in profit estimated at about 40 percent. About 40 tons have been marketed out of an estimated potential of 400 tons (MSSRF 2002). So even if all pineapples are not certified as 'organic', this initiative has generated some significant benefits. Overall, the two-step intervention by the MSSRF produced clear effects in three years: it increased producers' net returns, lowered transportation costs, and helped sustain environmentally friendly practices. Unlike cassava, pineapple is not a competitor for minor millets; they are not competing in land, and both contribute to diet diversity in the region. This is one of the reasons why the MSSRF agreed to intervene in both cases simultaneously.

\section{From Kolli Hills to Koochi Hills: The cassava "invasion"}

As mentioned before, cassava has rapidly spread all over the Hills, to the point that local agricultural observers have jokingly nickname the area Koochi Hills, which can be translated as 'the cassava hills.' Cassava was introduced only recently, and local inhabitants told us that they had never heard of cassava before it was introduced in the mid 1990s.

Before meeting with the women's procurement group of Arippalapatty, we met all its participants in the field preparing the ground for sowing operations of cassava in a rather orderly manner. They used line-sowing techniques with adequate spacing to plant the cassava seedlings on a red soil terrain that has been well prepared and leveled off. During our focus group meeting with them, we discussed the production of cassava and its development compared to minor millets.

When asked why they choose to cover all their fertile land with cassava cultivation, they first mentioned land management issues. Minor millets are ready in 3 to 4 months, and after planting millets, there are no clear or advantageous alternatives, in part because of the bad timing of the season. Thus, the land is not used for any other type of cultivation. In contrast, cassava takes ten months to grow and thus is not wasting land space. In addition, minor millets provide one time harvest with partial cash payments, whereas, because of the contractual arrangement with the purchasing company, farmers obtain revenue from cassava throughout the whole year. The company provides support from the beginning of the season until the end and provides revenue that can amount to about Rs.10,000 /year. Overall, the net return from cassava per unit of land is estimated to be about Rs.5,000 for a season of 9 months, whereas returns from millet cultivation average at Rs.2,500 for a season of 3-4 months if sold in the market. Among minor millets, finger millets get better farm gate price (Rs. 9 per kg) compared to other minor millet crops, but they also consume more water and become a competing crop for rice paddy in valleys.

Cassava is the major ingredient supporting the sago industry located in the plains, which is used mainly for two purposes: first, to extract glucose for pharmaceutical purposes and starch for 
textile industries particularly well developed in the region of Coimbatore, located $100 \mathrm{kms}$ from Namakkal and Salem districts (the so called Manchester of South India with the heavy concentration of cotton and textile mills); and second, to produce sago pellets that can be used as equivalent of noodles for various food preparations such as porridge, crackers, and gruel. The incentive of the industry to develop a cassava production unit in the Kolli Hills is based on agronomic advantages and low cost family laborers that seemingly compensate for the additional transport cost on the only road that leads to the plains. The industry also found that cassava is subject to fewer pests in high altitude and grows well with the local fertile land without any intensive external input. Even though cassava requires good water resources, which tend to become scarce in certain parts of the plains with more frequent occurrences of drought and depletion of the water resource, it is not a problem with the heavier precipitation in the Kolli Hills environment. The main inputs used are organic fertilizers. Chemical fertilizers are not encouraged by the MSSRF and do not seem to be considered necessary by the company in the Hill agro-ecosystem. We also asked women why they use the proper sowing techniques to plant the cassava and neglect to do the same for minor millets. They replied that they do not use line sowing and proper spacing technique for minor millets because the millets are planted on the slopes of the hills in rocky terrain, which makes it difficult to follow the same practices.

Based on information we gathered and group practice observation, cassava producers within each community tend to help each other during sowing and harvesting periods. The sowing is done by all female members of the community on each individual field. This shared effort helps to gain precious time before the rainy season. On the other hand, we witnessed a village-wide collection of cassava tubers, where the shared effort of all men and women helped to collect and transport the tubers by head loads to the shared truck hired for this occasion. 
Comparison: The Role of Collective Action in Marketing of Three Crops

Figure 5. A conceptual framework for development action

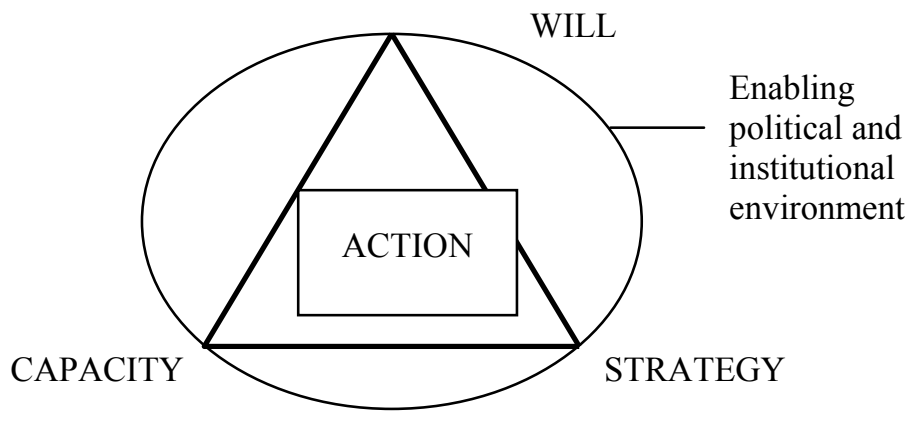

To better understand what the role of collective action is in the marketing chain for minor millets, pineapples and cassava, we propose to take a step back and evaluate this particular market development action in a more general conceptual framework as presented in Figure 5. The premise of this conceptual framework is that in the situation where there is an enabling political and institutional environment that allow individual actors to make their own decisions, and in a medium term horizon, there are three necessary conditions to the success of a development action at the local level:7 1) the will, motivation, or incentive to conduct this action; 2) the capacity to do so; and 3) a strategy or a plan of action. This conceptual framework can be applied to individual or group actions.

The comparison between marketing channels for cassava, minor millets, and pineapples in the Kolli Hills region reveals the crucial role of collective action for market development and successful commercialization of underutilized species. Table 4 summarizes the differences between these three markets in the Hills according to the three necessary conditions defined in the conceptual framework for development action, the supply- or demand-driven nature of the market development initiative, and the direction of the chain of order. Collective action occurs in all three markets at the level of production capacity by sharing labor and capital. However, the nature of incentives and the strategy adopted within each market differ widely, from purely individual in the case of cassava to

\footnotetext{
${ }^{7}$ We explicitly limit our conceptual framework to localized actions in a medium term horizon to make sure the political and institutional environment is exogenous. In a more general framework, in the long run, or at a larger scale, it is clear that the political environment would likely depend on individual incentives and therefore be endogenous to the system.
} 
purely collective in the case of minor millets. In addition, both the chain of order and nature of the market development initiative vary largely among the three crops.

Table 4. Comparison of the role of collective action in three agricultural markets in Kolli Hills

\begin{tabular}{|c|c|c|c|}
\hline & Minor millets & $\begin{array}{c}\text { Conventional and organic } \\
\text { Pineapples }\end{array}$ & Cassava \\
\hline Type of crop & Underutilized plant species & $\begin{array}{l}\text { High value product and niche } \\
\text { market }\end{array}$ & $\begin{array}{l}\text { High value } \\
\text { industrial crop }\end{array}$ \\
\hline Capacity & $\begin{array}{l}\text { Collective action: internal } \\
\text { lending }\end{array}$ & $\begin{array}{l}\text { Collective action: association of } \\
\text { producers, organic certification } \\
\text { fee and procurement groups }\end{array}$ & $\begin{array}{l}\text { Mostly individual, } \\
\text { collective action at } \\
\text { harvest and sowing } \\
\text { time }\end{array}$ \\
\hline Will & $\begin{array}{l}\text { Collective action: multiple } \\
\text { enterprises and coordinated } \\
\text { SHGs, lower economic } \\
\text { incentive in the short run. }\end{array}$ & $\begin{array}{l}\text { Individual and collective action } \\
\text { for organic producers: } \\
\text { association to obtain organic } \\
\text { certification (medium run } \\
\text { economic incentive) }\end{array}$ & $\begin{array}{l}\text { External funding } \\
\text { motivation, } \\
\text { individual } \\
\text { payments (short } \\
\text { run economic } \\
\text { incentive) }\end{array}$ \\
\hline Strategy & $\begin{array}{l}\text { Collective action: with } \\
\text { MSSRF audit and } \\
\text { participative selection, } \\
\text { agronomic improvement, } \\
\text { marketing enterprises }\end{array}$ & $\begin{array}{l}\text { Association with the MSSRF on } \\
\text { initial strategy but long term } \\
\text { production individual strategies }\end{array}$ & $\begin{array}{l}\text { Individual } \\
\text { contracts }\end{array}$ \\
\hline $\begin{array}{c}\text { Market } \\
\text { development }\end{array}$ & Supply-driven & Supply- and demand-driven & Demand-driven \\
\hline Chain of order & Bottom-up and top-down & $\begin{array}{l}\text { Top-down for conventional and } \\
\text { mixed for organic }\end{array}$ & Top-down \\
\hline
\end{tabular}

In the case of minor millets, the successful development of the market chain has been implemented with support from collective activities that satisfied the three necessary conditions. First, the decisions and motivations were based on group decisions after the discussions with MSSRF staff. Second, the capacity to set up a market was build via collective action: each enterprise decided to make it possible, even if it meant utilizing some land, buildings, or other resources to make sure that it would work. Finally, the agreed-upon strategy was a result of grassroots discussions within selfhelp groups, enterprises, and communities. By mixing SHGs, enterprises benefited from the combination of their financial resources when needed, particularly during the initial phase of market development. This system also encouraged interaction across SHGs. Furthermore, the shared capacity and common strategies reinforced the will of the collectivity to carry out this effort. The collective will is based on the fact that every enterprise knows their necessary steps in the process for the common good. Besides, there are multiplier effects along the chain: once the group is set up, the development of the market with the necessary capacity may encourage others to enter in the action. 
The common decisions can ensure that everyone is motivated, and the common motivation will enhance the capacity.

The degree of collective action in the marketing channel of organic pineapples could be considered intermediate between minor millets and cassava. Men's and women's self-help groups pooled the produce from various areas to ensure quality while marketing at collection centers. Collection was carried out under the supervision of IEEFL. This process contributed to instill a feeling of collective ownership and provided SHG members with business skills (MSSRF 2002). Thus, pineapple producers share labor-intensive tasks, but they go beyond that with the procurement self-help groups and the association pooling funds in order to get organic certification annually. As in the case of minor millets, the chain involves groups that are absolutely essential for product, information, and money flows. But unlike the case of minor millets, there is no effort to market the crop beyond the market link initiated by the MSSRF: there is no product development, no packaging, and no consistent effort by all producers to maintain the production. Collective action exists as a common motivation to strengthen the capacity and to help with common strategy during the intervention. In other words, the intervention to improve the market chain links supply-driven and demand-driven factors. Action taken by each producer individually may be motivated by individual factors, but will be driven by a common strategy and semi-pooled capacity. Furthermore, unlike the two other marketing channels, this chain involves both top-down and bottom-up chains of order.

Finally, for cassava, it is clear that collective action is involved in labor-intensive tasks as a way to put together human capacity. At the same time, unlike in the case of minor millets, each household can be individually contracted with the company, so there is no need for a common strategy and common will: if the neighbor stops to grow cassava, the others will still be able to grow it and sell it. In other words, contract farming tends to dissolve the need for collective action on each necessary condition for proper action. The chain for cassava is driven by the cassava industry, and the chain of orders is top-down. In contrast, the minor millets chain in its inception is obviously supplydriven, in the sense that local producers and chain actors are trying to develop a market and link their products with potential demand. The chain of order for minor millets is based on collective "grassroots" decisions and, as such, can be considered bottom-up. 


\section{CONCLUSIONS}

\section{Market Development through Collective Action for Underutilized Species}

The successful example of marketing development of minor millets in the Kolli Hills of Tamil Nadu shows that collective action initiatives play an essential role in market access for smallholders in the case underutilized crops. Collective action is shown to be necessary for the successful marketing development phase and will most likely be needed for a sustained effective marketing strategy.

Underutilized species have the specific particularity of facing a weak demand, mostly due to the lack of awareness about the product attributes and poor public and scientific knowledge, which tends to be associated with the lack of agricultural research. Unlike pineapple, minor millets are not locally, regionally, and internationally known by consumers. Unlike cassava, minor millets are not driven by a robust industrial demand. As a result, developing a market for an underutilized crop is most specifically a question of demand expansion.

Expanding demand is difficult and has to be done concurrently with the development of the market chain. Since these underutilized crops are only used locally in rural communities of developing countries, mostly by smallholder farmers, any successful market development and demand expansion has to start from this basis of production. Because the lack of demand for these crops makes them uncompetitive compared to existing cash crops with well established demand, the individual economic incentives to market them are rather weak, if not totally absent. For all these reasons, collective action initiatives are absolutely necessary to the development of a robust marketing channel. In the case of minor millets, collective action has played an essential role in the promotion and awareness campaigns on their uses through the development of new recipes based on local traditions and the access to local temple festivals. Groups of local users help to understand current and past uses of the products, build proper ways to develop new uses, and promote them. Groups of local producers are also the basis for any successful development of the supply chain. Pooling resources, realizing scale economies, sharing information, developing a community incentive, and transforming traditional recipes into new cultural delicacies are undoubtedly the benefits of collective action around minor millets. Market development without a driving demand will require capacity, strategy, and a will that can only be obtained through collective initiatives.

The comparison of the three markets can also help us to understand the possible evolution of markets. Without a robust and strong demand, the challenge of market development is first to create a 
small but robust production and marketing chain while developing uses and linking products to potential demand through promotion and awareness campaigns. All underutilized crops are facing these challenges. If the approach is successful, demand becomes sufficient to sustain a market over time. At that point, the crop will potentially attract competitors, thus driving the costs and prices down. If this happens too quickly, the incentive to continue marketing the crop could falter to the point that the crop becomes unprofitable for market chain actors. This is the reason why Gruere et al. (2006) argue that marketing should involve some type of branding in the original region, and from the beginning, marketers should consider product differentiation strategies. The minor millets initiative in the Kolli Hills set up a local brand with organic certification, while proposing recipes and packaging designs under specific format that makes their products well differentiated.

The goal of the marketing development for these minor millets is to create a robust product niche in the region. If it goes beyond that to the generalized use of the crop over the years, it could potentially become a commonly used high value agricultural product with a strong and sustainable demand. This would result in increasing capacity and moving towards the cassava model, therefore generating higher revenues. At the same time, this transition towards individual marketing channels may have negative spillover effects if not well analyzed, with less local consumption of nutritious millets in favor of less nutritious foods which require the use of more intensive production techniques. However, it is more likely that the realistic objective of the minor millets market development is closer to the organic pineapple example, where the market chain is well organized and driven by a specific high quality niche market demand.

More generally, our comparison of group involvements in three parallel marketing channels can help us draw a few lessons related to the use of collective action to facilitate market access for smallholder farmers. In Kolli Hills, three different types of market development occurred for these crops following different models and reaching different outcomes. The example of cassava and its ability to provide better remuneration to farmers shows that a demand driven market development can be an effective way of linking smallholders to the market. It suggests that collective action aiming at directing smallholders towards highly demanded crops can pay-off. But, at the same time, in our case, cassava production has generated negative externalities in production and consumption: the more it is grown, the less minor millets have been grown and consumed to the detriment of the local diets. The rapid market demand for the crop has also encouraged farmers to practice some type of intensive monoculture that is likely to deplete soil fertility. ${ }^{8}$ Thus, demand-driven interventions aiming to

\footnotetext{
${ }^{8}$ Interestingly, a recent field study by Damiana Astudillo (Bioversity International) in an elevated region in the South of Bolivia on the production and use of quinoa, a formerly underutilized crop that has now become a cash crop for local producers, has had similar negative production and consumption effects as cassava in Kolli Hills.
} 
enhance market access for smallholders have to balance the generation of individual gains with potential externalities. On the other hand, supply driven models of market development are well adapted to the case of local or traditional crops, but they seem to be more difficult to set up and require outside interventions.

In the case of minor millets, it is obvious that the role of the Foundation has been preponderant in the success of market development. Without its participation, the market for minor millets would not have developed. At the same time, its role can be considered as that of a facilitator for market development rather than a leader-financial supporting institution. In the case of Kolli Hills, in order to market any non-commercial product successfully, an external facilitator was required for several reasons. First of all, this area is a hill based eco-system and a very niche based agroecological system. Secondly, the people living in the Kolli Hills belong to tribes that are culturally more closed and autarkic. In addition, the accessibility of the Kolli Hills is a significant market constraint as many communities in the hills are still not connected by roads.

When crops like pineapple and cassava were introduced to Kolli Hills system from external agents, the trading system came along with them. But the concept of 'value-addition' such as 'organic' was not introduced before the MSSRF started its interventions. Moreover, crops like cassava and pineapple were attracted to traditional trading methods through commission agents, so loans and advances/credit availability to farmers was not a problem. In the case of minor millets, traditional subsistence crops that were not formally traded, the monetary help was not available through any means. Hence, there was a need for an external facilitator to help with the creation of incentives through value-addition for some products (minor millets or pineapples) or even with the creation of markets for other products (minor millets).

Even if the intervention of the concerned NGO as a facilitator played a very important role in market development for minor millets, the role of intervention by an outside institution cannot be generalized to all cases of underutilized plant species. The example of minor millets represents a case without an established market; there was no significant incentive for market creation in the presence of competing economic opportunities. In other words, individual local inhabitants did not have the motivation to create a market for these traditional crops. Therefore, our case study supports the argument that facilitation through a NGO is necessary to develop inexistent markets in cases where the underutilized crops are under economic pressure. But other cases of underutilized plant species will likely differ: some had a past market use, and others suffer from an existing but underdeveloped

As demand became stronger, smallholders became richer, lost their interest in collective action, consumed less of the nutritious quinoa for more staple rice, and practiced monoculture at the detriment to their soil. 
market. In these cases, a simple improvement (such as market coordination) coming from the community itself and with very limited outside intervention can result in significant market and value improvements.

Beyond that, and even with strong and robust support from groups of local users, policy makers need to evaluate whether marketing development is an effective sustainable solution for agrobiodiversity conservation. The driving force of this market development intervention was based on the provision of public goods, notably the conservation of traditional crops, their expanded use for nutritional purposes, the conservation of crop biodiversity, and sustainable agricultural practices. Yet, because competitive crops provide much larger private benefits, the example of minor millet in the Kolli Hills shows that there may be significant issues with the use of this strategy, as discussed in the following section.

\section{The Limits of Market Development for Agrobiodiversity}

\section{Fragile and limited demand: What is the real market potential?}

Measuring the potential market for a new or re-introduced good is very difficult.

Underutilized products have an unexploited economic potential, which can be assessed based on past use, current trends in the local regional or international markets, and the properties of the products as compared to other substitute products. Gruère et al. (2006) argue that the gap in knowledge among local users and between local and regional users can be used as a partial measurement for the difference between the observed and potential value of underutilized species.

Minor millets have been widely used in this region of India, but they have been progressively replaced by other cereal alternatives both in production and consumption. Outside of the Hills, particularly in the neighboring plain area, it is difficult to find farmers that still devote some of their land to minor millets. Without processing and value addition, it is arguably impossible to market millets profitably, so the production incentives are very limited in most areas. On the consumption side, minor millets also face a number of constraints. In August 2006, we conducted a parallel focus group of thirty small and medium cotton farmers in a village in the plains of the Salem district, which belongs to the targeted scope for regional marketing development of minor millets from Kolli Hills. At the end of the meeting we asked these male and female farmers about their current consumption of minor millets. Most of them said they do not consume minor millets anymore. They argued that rice is much easier to prepare. Minor millet processing is very difficult physically. Moreover, women do not have the time to process millets and do not know how to prepare and cook them anymore. Besides, household members can buy rice for a very low price under public procurement systems. 
Each family is entitled to $20 \mathrm{~kg} /$ month for a very low price, which makes it almost free. Rice production is not profitable in the area because of the fertilizer needs and cost that exceed the revenue, but it constitutes the staple product of the local diet.

These simple remarks taken from a group of rural consumers reveal that there are a number of challenges to be overcome. The regional availability of processed minor millets could help significantly in the rehabilitation of this product among the local population, but it will not be sufficient. First, rice is almost freely provided to these families, so it is clear that competition with subsidized crop is a major constraint. Second, even without the price difference, the traditional cooking know-how for minor millets has been lost. This is where the recipe leaflets attached to the packaged products marketed by the Kolli Hills community could play a role. However, including written recipes might not be sufficient for consumers to get interested in the product again, as the share of consumers reading food labels may not be high. Promotion and perhaps cooking demonstrations would be other possible ways to effectively deliver the message.

Another difficult issue not explicitly mentioned in this paper is the change in taste; local inhabitants may be used to eating rice and other grains several times every day, and replacing rice with minor millets could be a challenge. In other words, fighting against a long term trend would require very visible promotion and awareness campaigns.

All these factors show that there may be a market potential for minor millet products regionally outside of the Hills, but it could be seriously limited. There is a wide difference between establishing a marketing niche and reaching significant market shares in local food consumption. But even with the establishment of a niche market for minor millets, the effort will need to be sustained and expanded to particular groups of the population that could constitute a stable segment of consumers. This segment could include health conscious urban consumers, diabetic persons, and perhaps even tourist outlets as an initial target.

As in the case of the initial phase of market development, collective action has a significant role to play in establishing a successful promotional strategy and implementing it. Pooled resources, pooled expertise, and pooled capacity will be critical to the expansion of a robust demand for minor millets or any other underutilized plant product. But it remains a necessary but not a sufficient condition for successful commercialization. Group coordination and concerted efforts will not prevent the failure of a market to sufficiently establish a niche if the market potential is not sufficient in the first place, or if the competition is distorted by production and consumption subsidies. 


\section{Sustaining the incentive: Private versus public benefits and the role of collective action}

Economic incentives have arguably been the main driver for the expansion of cassava in the Kolli Hills. One has to recognize the competitive edge of cassava cultivation as compared to minor millets. MSSRF (2002) reports that though the market linkages established by its initiatives encouraged local people to grow minor millets, practical constraints still discourage them from expanding their production. In particular, various land races of minor millets in Kolli Hills are grown in over 250 hamlets in 16 revenue villages, mostly on undulating terrains, which make complete procurement and homogenous sales challenging. The financial constraint is another obstacle to the success of the market initiative: there is no insurance mechanism to compensate the risk of loss.

The basic costs and returns of production also differ widely with cassava cultivation, which is the next competitive opportunity. As previously mentioned, returns from cassava production per unit of land largely surpass those obtained from minor millets. Even with a higher cost of production, cassava simply provides more returns to the individual households. This extra income expands the purchasing power of producing households. As a consequence, it increases their access to utilities, such as sending their children to distant and good schools, receiving good health care, and enjoying other luxuries from external markets with the surplus income earned from growing cash crops.

However, a comparison of the external costs and benefits associated with both systems clearly rule in favor of the traditional system using minor millets. From the environmental point of view, the production of cassava or any other cash crop leads to a number of adverse effects. The foremost is land degradation, which is caused mainly by the slash and burn approach followed by constant tillage, removal of inherent fertility, addition or dumping of fertilizers (artificial) in to the soil system, and exhaustion of soil fertility by intensive cropping. Secondly, local honey production is under threat because of the lack of suitable pollen that was available in plenty with the traditional system for the wild bees. Thirdly, uncertainty facing the existing cash cropping system is another threat faced by the farming community as it was clearly proved a few years ago: in the context of heavy rains, the entire cassava acreage was washed out because of lodging, whereas traditional millets survived through the heavy rains and drought. In addition, the introduction of cash crops also led to the appearance of new pests and diseases in the ecosystem. And lastly, the expansion of cassava cultivation led to the loss of biodiversity in terms of plant species, especially minor millets and medicinal plants, from the ecosystem. To each of these negative effects of cassava production corresponds a neutral or positive effect associated with the traditional system of cultivation of minor millets (Nagarajan 1999). 
Because of this difference in private and public values, this competition between crops calls for a public intervention to internalize the negative externalities of cassava cultivation while sustaining the production of minor millets. Market development helped make the minor millets generate income above the subsistence level, but this income is not sufficient to reduce the private comparative advantage of cassava cultivation. The most straightforward answer to this problem would be a direct subsidy to minor millets producers up to a certain level that is deemed sufficient to maximize the social benefit of growing both crops.

The current MSSRF strategy is primarily based on a market solution. If the demand expansion phase is successful and the groups are sufficiently able to maintain a strong and durable participation of their members, the project will be a complete success with the sustainable creation of a robust market for minor millets in the area for the benefit of the poor and the conservation of agrobiodiversity. If, however, the long term demand is not sufficient and the groups are not sustained over a generation, minor millets will likely be neglected and may progressively be marginalized years after the intervention.

At the same time, one could argue that political actions in support of minor millets led by the MSSRF at the state and federal level show that the overall strategy of the foundation does not exclude the use of public support. Lobbying for the inclusion of minor millets into public meal programs, such as public procurement and child feeding programs, is a way to subsidize demand for these crops. International observers have also suggested lobbying for the use of grains from nutritionally advantageous underutilized species in military rations to further support the demand for these products. If successful, these types of public political approaches could effectively complement the local market demand expansion and enable underutilized species like minor millets to thrive in their regions of production for decades. 


\section{REFERENCES}

Food and Agriculture Organization of the United Nations (FAO). 1996. Global Plan of action for the conservation and sustainable utilization of plant genetic resources for food and agriculture. Section 12. Rome, Italy: FAO.

Gopinath, L. R. 2006. Millet marketing model in the Kolli Hills. Unpublished Project Report Document submitted to IPGRI, Rome, MSSRF Field Station, Namakkal and Kolli Hills, India.

Gruere, G.P., A. Giuliani, and M. Smale. 2006. Marketing underutilized plant species for the benefit of the poor: A conceptual framework. EPT Discussion Paper 154. Washington DC: International Food Policy Research Institute.

Kumaran, M. 2004. Assessment of development interventions of M.S. Swaminathan Research Foundation in Kolli Hills using geographical information systems. Unpublished: Project Report for Master of Science in Geoinformatics, Department of Rural Development, Gandhigram Rural Institute-Deemed University, Gandhigram, Tamil Nadu, India.

M.S. Swaminathan Research Foundation (MSSRF). 2002. Rural and tribal women in agrobiodiversity conservation. Food and Agriculture Organization (FAO) RAP publication 2002/08. Bangkok, Thailand: FAO Regional Office for Asia and the Pacific.

M.S. Swaminathan Research Foundation, Namakkal. 2004. Mouthwatering gourmets from traditional foods of Kolli Hills. Published booklet from the Field station (MSSRF), Kolli Hills and Namakkal.

Nagarajan, L. 1999. Conservation at whose cost: An holistic view. Un-published paper prepared as a part of the course AGECON 8001--Economics of Environment, Department of Applied Economics, University of Minnesota, St. Paul, Minnesota.

Nagarajan, L. and M. Smale. 2005. Local seed systems and village-level determinants of millet crop diversity in marginal environments of India. EPTD Discussion Paper 135. Washington DC: International Food Policy Research Institute.

Pradeep, V. and J. Rajasekeran. 2006. Classification and characterization of self-help groups (shg's) enterprises in Kolli Hills developed by MSSRF. Unpublished report submitted for Master of Arts in Social Works, Department of Social Work. Madurai, India: The American College.

Prescott-Allen, R. and C. Prescott Allen. 1990. How many plants feed the world? Conservation Biology 4: 365-374.

Rengalakshmi, R., S. Mishra, S.S. Chaudhury, E.D.I. Oliver King and T. Ray. 2006. When is knowledge power? Gendered knowledge and women's changing status in two agrobiodiversity-rich locations (Kolli Hills and Jeyapore). Working paper in progress. Chennai, India: M.S.Swaminathan Research Foundation. 
Swaminathan M.S. 2006. Key note lecture for Avabai B Wadia Memorial Oration, Mumbai, The Tribune, July $16^{\text {th }} 2006$. 


\section{List of CAPRi Working Papers}

01 Property Rights, Collective Action and Technologies for Natural Resource Management: A Conceptual Framework, by Anna Knox, Ruth Meinzen-Dick, and Peter Hazell, October 1998.

02 Assessing the Relationships between Property Rights and Technology Adoption in Smallholder Agriculture: A Review of Issues and Empirical Methods, by Frank Place and Brent Swallow, April 2000.

03 Impact of Land Tenure and Socioeconomic Factors on Mountain Terrace Maintenance in Yemen, by A. Aw-Hassan, M. Alsanabani and A. Bamatraf, July 2000.

04 Land Tenurial Systems and the Adoption of a Mucuna Planted Fallow in the Derived Savannas of West Africa, by Victor M. Manyong and Victorin A. Houndékon, July 2000.

05 Collective Action in Space: Assessing How Collective Action Varies Across an African Landscape, by Brent M. Swallow, Justine Wangila, Woudyalew Mulatu, Onyango Okello, and Nancy McCarthy, July 2000.

06 Land Tenure and the Adoption of Agricultural Technology in Haiti, by Glenn R. Smucker, T. Anderson White, and Michael Bannister, October 2000.

07 Collective Action in Ant Control, by Helle Munk Ravnborg, Ana Milena de la Cruz, María Del Pilar Guerrero, and Olaf Westermann, October 2000.

08 CAPRi Technical Workshop on Watershed Management Institutions: A Summary Paper, by Anna Knox and Subodh Gupta, October 2000.

09 The Role of Tenure in the Management of Trees at the Community Level:

Theoretical and Empirical Analyses from Uganda and Malawi, by Frank Place and Keijiro Otsuka November 2000.

10 Collective Action and the Intensification of Cattle-Feeding Techniques a Village Case Study in Kenya's Coast Province, by Kimberly Swallow, November 2000.

11 Collective Action, Property Rights, and Devolution of Natural Resource Management: Exchange of Knowledge and Implications for Policy, by Anna Knox and Ruth MeinzenDick, January 2001.

12 Land Dispute Resolution in Mozambique: Evidence and Institutions of Agroforestry Technology Adoption, by John Unruh, January 2001. 
13 Between Market Failure, Policy Failure, and "Community Failure": Property Rights, CropLivestock Conflicts and the Adoption of Sustainable Land Use Practices in the Dry Area of Sri Lanka, by Regina Birner and Hasantha Gunaweera, March 2001.

14 Land Inheritance and Schooling in Matrilineal Societies: Evidence from Sumatra, by Agnes Quisumbing and Keijuro Otsuka, May 2001.

15 Tribes, State, and Technology Adoption in Arid Land Management, Syria, by Rae, J, Arab, G., Nordblom, T., Jani, K., and Gintzburger, G., June 2001.

16 The Effects of Scales, Flows, and Filters on Property Rights and Collective Action in Watershed Management, by Brent M. Swallow, Dennis P. Garrity, and Meine van Noordwijk, July 2001.

17 Evaluating Watershed Management Projects, by John Kerr and Kimberly Chung, August 2001.

18 Rethinking Rehabilitation: Socio-Ecology of Tanks and Water Harvesting in Rajasthan, North-West India, by Tushaar Shah and K.V.Raju, September 2001.

19 User Participation in Watershed Management and Research, by Nancy Johnson, Helle Munk Ravnborg, Olaf Westermann, and Kirsten Probst, September 2001.

20 Collective Action for Water Harvesting Irrigation in the Lerman-Chapala Basin, Mexico, by Christopher A. Scott and Paul Silva-Ochoa, October 2001.

21 Land Redistribution, Tenure Insecurity, and Intensity of Production: A Study of Farm Households in Southern Ethiopia, by Stein Holden and Hailu Yohannes, October 2001.

22 Legal Pluralism and Dynamic Property Rights, by Ruth Meinzen-Dick and Rajendra Pradhan, January 2002.

23 International Conference on Policy and Institutional Options for the Management of Rangelands in Dry Areas, by Tidiane Ngaido, Nancy McCarthy, and Monica Di Gregorio, January 2002.

24 Climatic Variablity and Cooperation in Rangeland Management: A Case Study From Niger, by Nancy McCarthy and Jean-Paul Vanderlinden, September 2002.

25 Assessing the Factors Underlying the Differences in Group Performance: Methodological Issues and Empirical Findings from the Highlands of Central Kenya, by Frank Place, Gatarwa Kariuki, Justine Wangila, Patti Kristjanson, Adolf Makauki, and Jessica Ndubi, November 2002. 
The Importance of Social Capital in Colombian Rural Agro-Enterprises, by Nancy Johnson, Ruth Suarez, and Mark Lundy, November 2002.

27 Cooperation, Collective Action and Natural Resources Management in Burkina Faso: A Methodological Note, by Nancy McCarthy, Céline Dutilly-Diané, and Boureima Drabo, December 2002.

28 Understanding, Measuring and Utilizing Social Capital: Clarifying Concepts and Presenting a Field Application from India, by Anirudh Krishna, January 2003.

29 In Pursuit Of Comparable Concepts and Data, about Collective Action, by Amy Poteete And Elinor Ostrom, March 2003.

30 Methods of Consensus Building for Community Based Fisheries Management in Bangladesh and the Mekong Delta, by Parvin Sultana and Paul Thompson, May 2003.

31 Formal and Informal Systems in Support of Farmer Management of Agrobiodiversity: Some Policy Challenges to Consolidate Lessons Learned, by Marie Byström, March 2004.

32 What Do People Bring Into the Game: Experiments in the Field About Cooperation in the Commons, by Juan-Camilo Cárdenas and Elinor Ostrom, June 2004.

33 Methods for Studying Collective Action in Rural Development, by Ruth Meinzen-Dick, Monica Di Gregorio, and Nancy McCarthy, July 2004.

34 The Relationship between Collective Action and Intensification of Livestock Production: The Case of Northeastern Burkina Faso, by Nancy McCarthy, August 2004.

35 The Transformation of Property Rights in Kenya's Maasailand: Triggers and Motivations by Esther Mwangi, January 2005.

36 Farmers' Rights and Protection of Traditional Agricultural Knowledge, by Stephen B. Brush, January 2005.

37 Between Conservationism, Eco-Populism and Developmentalism - Discourses in Biodiversity Policy in Thailand and Indonesia, by Heidi Wittmer and Regina Birner, January 2005.

38 Collective Action for the Conservation of On-Farm Genetic Diversity in a Center of Crop Diversity: An Assessment of the Role of Traditional Farmers' Networks, by Lone B. Badstue, Mauricio R. Bellon, Julien Berthaud, Alejandro Ramírez, Dagoberto Flores, Xóchitl Juárez, and Fabiola Ramírez, May 2005.

39 Institutional Innovations Towards Gender Equity in Agrobiodiversity Management: Collective Action in Kerala, South India,, by Martina Aruna Padmanabhan, June 2005. 

and Biodiversity from Legal Pluralism, by Melanie G. Wiber, July 2005.

41 Who Knows, Who Cares? Determinants of Enactment, Awareness and Compliance with Community Natural Resource Management Bylaws in Uganda, by Ephraim Nkonya, John Pender, Edward Kato, Samuel Mugarura, and James Muwonge, August 2005.

42 Localizing Demand and Supply of Environmental Services: Interactions with Property Rights, Collective Action and the Welfare of the Poor, by Brent Swallow, Ruth MeinzenDick, and Meine von Noordjwik, September 2005.

43 Initiatives for Rural Development through Collective Action: The Case of Household Participation in Group Activities in the Highlands of Central Kenya, By Gatarwa Kariuki and Frank Place, September 2005.

44 Are There Customary Rights to Plants? An Inquiry among the Baganda (Uganda), with Special Attention to Gender, by Patricia L. Howard and Gorettie Nabanoga, October 2005.

45 On Protecting Farmers' New Varieties: New Approaches to Rights on Collective Innovations in Plant Genetic Resources by Rene Salazar, Niels P. Louwaars, and Bert Visser, January 2006.

46 Subdividing the Commons: The Politics of Property Rights Transformation in Kenya's Maasailand, by Esther Mwangi, January 2006.

47 Biting the Bullet: How to Secure Access to Drylands Resources for Multiple Users, by Esther Mwangi and Stephan Dohrn, January 2006.

48 Property Rights and the Management of Animal Genetic Resources, by Simon Anderson and Roberta Centonze, February 2006.

49 From the Conservation of Genetic Diversity to the Promotion of Quality Foodstuff: Can the French Model of 'Appellation d'Origine Contrôlée' be Exported? by Valérie Boisvert, April 2006.

50 Facilitating Collective Action and Enhancing Local Knowledge: A Herbal Medicine Case Study in Talaandig Communities, Philippines, by Herlina Hartanto and Cecil Valmores, April 2006.

51 Water, Women and Local Social Organization in the Western Kenya Highlands, by Elizabeth Were, Brent Swallow, and Jessica Roy, July 2006.

52 The Many Meanings of Collective Action: Lessons on Enhancing Gender Inclusion and Equity in Watershed Management, by Laura German, Hailemichael Taye, Sarah Charamila, Tesema Tolera, and Joseph Tanui, July 2006. 
53 Decentralization and Environmental Conservation: Gender Effects from Participation in Joint Forest Management, by Arun Agrawal, Gautam Yadama, Raul Andrade, and Ajoy Bhattacharya, July 2006.

54 Improving the Effectiveness of Collective Action: Sharing Experiences from Community Forestry in Nepal, by Krishna P. Achyara and Popular Gentle, July 2006.

55 Groups, Networks, and Social Capital in the Philippine Communities, by Marie Godquin and Agnes R. Quisumbing, October 2006.

56 Collective Action in Plant Genetic Resources Management: Gendered Rules of Reputation, Trust and Reciprocity in Kerala, India, by Martina Aruna Padmanabhan, October 2006.

57 Gender and Local Floodplain Management Institutions--A case study from Bangladesh, by Parvin Sultana and Paul Thompson, October 2006.

58 Gender Differences in Mobilization for Collective Action: Case Studies of Villages in Northern Nigeria, by Saratu Abdulwahid, October 2006.

59 Gender, Social Capital and Information Exchange in Rural Uganda, by Enid Katungi, Svetlana Edmeades, and Melinda Smale, October 2006.

60 Rural Institutions and Producer Organizations in Imperfect Markets: Experiences from Producer Marketing Groups in Semi-Arid Eastern Kenya, by Bekele Shiferaw, Gideon Obare and Geoffrey Muricho, November 2006.

61 Women's Collective Action and Sustainable Water Management: Case of SEWA's Water Campaign in Gujarat, India, by Smita Mishra Panda, October 2006.

62 Could Payments for Environmental Services Improve Rangeland Management inCentral Asia, West Asia and North Africa? by Celine Dutilly-Diane, Nancy McCarthy, Francis Turkelboom, Adriana Bruggeman, James Tiedemann, Kenneth Street and Gianluca Serra, January 2007.

63 Empowerment through Technology: Gender Dimensions of Social Capital Build-Up in Maharashtra, India, by Ravula Padmaja and Cynthia Bantilan, February 2007.

64 Gender and Collective Action: A Conceptual Framework for Analysis, by Lauren Pandolfelli, Ruth Meinzen-Dick, and Stephan Dohrn, May 2007.

65 Gender, Wealth, and Participation in Community Groups in Meru Central District, Kenya, by Kristin E. Davis and Martha Negash, May 2007.

66 Beyond Group Ranch Subdivision: Collective Action for Livestock Mobility, Ecological Viability, and Livelihoods, by Shauna BurnSilver and Esther Mwangi, June 2007. 
67 Farmer Organization, Collective Action and Market Access in Meso-America, by Jon Hellin, Mark Lundy, and Madelon Meijer, October 2007.

68 Collective Action for Innovation and Small Farmer Market Access: The Papa Andina Experience, by André Devaux, Claudio Velasco, Gastón López, Thomas Bernet, Miguel Ordinola, Hernán Pico, Graham Thiele, and Douglas Horton, October 2007. 